\title{
THE EFFICIENCY OF QUIZLET-BASED EFL VOCABULARY LEARNING IN PREPARING UNDERGRADUATES FOR STATE ENGLISH EXAM
}

\author{
Olha Chaikovska \\ State Agrarian and Engineering University in Podillia, Kamianets-Podilskyi, Ukraine \\ olgachaikovskaya@ukr.net \\ Lesia Zbaravska \\ State Agrarian and Engineering University in Podillia, Kamianets-Podilskyi, Ukraine \\ olzbaravska@gmail.com
}

\begin{abstract}
Students' EFL learning experience in the rural context is poorer in comparison to urban quality of education. More than $70 \%$ of students at the State Agrarian and Engineering University in Podillia are from rural areas. To reduce rural-urban disparities in academic learning the university teachers should use high-quality instruction techniques that can make the process of studying both effective and motivating. The traditional methods of EFL teaching no longer satisfy the needs of modern society. Hence, technology applications need a theoretical foundation based on experimental surveys to determine the strategies for effective EFL learning. This research paper was conducted to examine the possibility of utilising such MALL technology like Quizlet in improving EFL learners' vocabulary acquisition. A brief review of scholarly literature published from 2005-2019 on Quizlet implementation in foreign language learning showed that there are many studies on the benefits of using Quizlet in EFL vocabulary acquisition. However, the research papers on the principles and strategies for adequate Quizlet-based learning in Ukrainian higher educational institutions are still lacking. Pre- and post-experimental questionnaires, pre- and post-experimental tests were adopted as tools for data collection. The results of the experiment have proven the proposed hypothesis. After utilising Quizlet and using spaced repetition technique for vocabulary learning to prepare undergraduates to state English exam, the results proved that the learners of the experimental group improved their level of EFL vocabulary at the post-test.
\end{abstract}

Keywords: Quizlet; EFL; vocabulary; experimental study; spaced repetition; intensive language courses.

\section{Introduction}

More than 1.5 million students are currently enrolled in higher education institutions in Ukraine. However, the principles and strategies for our national system of education have begun to change more recently. Ukrainian education is turning its focus from increasing quantity of universities and students to improving the quality of education, bringing up competitive specialists to keep up with surging demand of the world labour market.

Particular attention is paid to foreign language competence. Foreign language fluency that is measured according to the Common European Framework of Reference for Languages is one of the important conditions for becoming an equal member of the European community. The development of foreign language skills will help to encourage the study and labour mobility within the European Union. Ex-minister of Ministry of Education and Science of Ukraine Lilia Hrynevych emphasised that foreign language competence is very important for a specialist of each sphere. Current data published on the official website of the Ministry of Education and Science of Ukraine show that our country takes the 28th place among 32 European countries according to foreign language proficiency shows that our country loses its potential. The first steps have already been done by the Ministry of Education and Science of Ukraine. The concept of EFL (English as a foreign language) development provides the creating of extracurricular intensive language courses and clubs. B1 level of EFL competence will be obligatory to enter the university and B2 level to get the diploma of a bachelor and get Master degree and degree of Doctor of Philosophy. In the nearest future students of all specialities will have to pass the general final testing in a foreign language. The Concept of the English language development in higher education declares that till 2023 the majority of the students are supposed to have the appropriate level of the language competence. Besides, the Ministry of Education of Ukraine is going to provide regular language screenings and recommends teaching a part of major subjects in English (Official site of Ministry of Education and Science of Ukraine, 2019). These changes influenced both teachers and students. As far as university teachers of field-related subjects are concerned, they have to pass a B2 exam and get the official internationally recognised certificate, have publications in Scopus or Web of Science indexed journals and do an internship in the EU countries or participate in international conferences.

Chaikovska, O. \& Zbaravska, L. (2020). The efficiency of quizlet-based EFL vocabulary learning in preparing undergraduates for state English exam. Advanced Education, 14, 84-90. https://doi.org/10.20535/2410-8286.197808 


\section{Literature review}

The mentioned above Concept of the Ministry of Education and Science of Ukraine emphasises the importance of free online courses for students' self-study and education. Up-to-date digital resources are seen as a solution to the current need for increasing the level of language proficiency in short terms. That is why such characteristics of a modern language teacher as the ability to constant self-development and, consequently, the desire to adopt modern web-based technologies in his or her teaching are very important. According to Taj et al. (2016) "technological advances in the last quarter of the last century have made it mandatory for the teachers to employ technology as a tool to help in the process of teaching and learning" (p. 82) and CALL environment is an effective way to promote vocabulary acquisition (Kiliçkaya \& Krajka, 2010; Stockwell, 2010). Today "social media technologies, the potential of comics, webinars and on-line courses are used to make learning the foreign language both effective and interesting" (Chaikovska, Zbaravska \& Bilyk, 2019, p. 1915). Recent research (Miangah \& Nezarat, 2012) has found that "mobileassisted learning is characterized by its potential for learning to be spontaneous, informal, personalized and ubiquitous ... is reinforced when people encounter a shortage of free time as the result of working longer hours" (p. 309).

The analysis of existing literature on the topic showed that all the scientists agree that the implementation of such a popular Mobile-Assisted Language Learning tool as Quizlet can benefit EFL study within a university context. The questionnaires, pre- and post-tests results statistically proved the usefulness ease of use, and behavioural intention to use Quizlet (Dizon, 2017, p. 40). Quizlet provides the ability to transform learning into the active cooperative process (Dizon, 2017; Sanosi, 2018) and is designed to meet the need of autonomous learners (Dizon, 2017). According to Sanosi (2018), "the effect of Quizlet on vocabulary acquisition through the application of digital flashcards allows learners to share resources and interact in ways unthinkable with paper resources" (p. 76). Education researchers admit that Quizlet provides a novel, enjoyable way to learn vocabulary; moreover, it can boost the test scores in students who extensively use Quizlet by 6\% and "maintain student motivation and overall output" (Lander, 2015, p.379). Barr (2016) hopes that these activities will not only play a role in improving learners' test scores, but also "expanding their active vocabularies, their confidence, and their enjoyment studying and using the language" (p. 47). Quizlet, an excellent teacher-student-friendly online application and a website, is more effective than paper flashcards (Andarab, 2017). At the same time, some scientists come to the conclusion that "digital flashcards help students at lower levels to achieve higher vocabulary gains than when they use paper flashcards" (Ashcroft, Cvitkovic \& Praver, 2018, p. 26). The most advanced group of students in this study, however, did equally well with digital and paper flashcards. Most studies suggest different ways to be used to transform teaching and learning of vocabulary with Quizlet. The literature reviewed showed that Quizlet features imply that it can be considered "a good candidate for both teachers and students for vocabulary instruction and learning" (Sanosi, 2018, p.76).

Our paper follows the track of previous studies to evaluate the efficacy of Quizlet-based instruction in EFL vocabulary acquisition with A2 level university students who didn't use technology as a learning tool. The psychological approach is applied to investigate the influence of Ebhherhouse forgetting curve on quick and permanent memorisation of new words. To achieve this, the study tests the following hypothesis: H1. Quizlet provides quick and effective vocabulary acquisition at extracurricular intensive foreign language courses and can be used in preparing undergraduates for the state English exam. H2. Scheduling Quizlet activities based on Ebhherhouse forgetting curve and spaced repetition technique increase vocabulary acquisition at $5 \%$.

\section{Methods}

Two groups of A2 level EFL learners (experimental $(n=25)$ and control $(n=25))$ participated in the research. All the participants were the third-year students majoring in Electrical Engineering, Agronomy and Veterinary Medicine. Such ethical principles as students' voluntary participation, informed consent (all the students were informed about the procedure of the experiment and gave their consent to participate), anonymity and confidentiality were implemented in the study. Both groups started extracurricular intensive EFL courses at the same time, had a similar curriculum and course longevity (72 hours, 2 periods a week). The intensive EFL course aimed to prepare the students for the state English exam to start a Master course. The participants of the experiment had foreign language classes only during the autumn semester at their first academic year. This exam consists of two parts: "Reading" and "Use of English". According to the general 
testing curriculum, students must know about 2.500 words on the following topics: personal sphere (family relationships, character, daily routine, healthy diet, hobby, plans for future), public sphere (weather, environment, travelling, art, sport, literature, mass media, shopping, science, cuisine, holidays and traditions, exhibitions and museums, television and theatre, international organisations), education (university life, the system of education, job, foreign languages). As far as grammar is concerned the learners will cover primarily all grammar items. As can be seen from the above, we had to study basic grammar units, vocabulary and to examine test-taking strategies. That is why during the experiment the first part of the EFL class was focused on grammar theory and exercises, the second part was concerned vocabulary acquisition and strategies for developing reading skills. Consequently, to process the texts at a faster pace the students had to expand their vocabulary bank in a short period. The learners were asked to install Quizlet (https://quizlet.com) and learn the vocabulary through this online platform.

The researcher designed the learning sets according to grammar and vocabulary units. Much attention has been drawn to root words formed by adding suffixes and prefixes. To help the students to remember as many words as possible we also acquired synonyms and antonyms, phrasal verbs and idioms.

During our experiment, we grouped the words in sets according to the taught units. Such a procedure made it possible to create the sets, add common root words, synonyms, antonyms, word collocations during the EFL class. Remembering of the words through Quizlet in our EFL classroom included the following instructions: taping the translation of the word, identifying the picture in the circle and taping the correct word, to show on the picture the written word, spelling the word, picture quizzes, guessing games, matching games. We didn't do all Quizlet based activities during EFL class. The most interesting learning modes including games, quizzes and some collaborative activities the students did outside the university.

This study utilised an experimental research design including the diagnostic test to determine the level of language competence (the students took free online English grammar and vocabulary test from British Council), a pre-experimental questionnaire, pretest, post-test and a post-experimental questionnaire. The preexperiment start-of-semester questionnaire was used to gather information about the student preferences for using Mobile technology on-and off-campus. The survey was designed by the authors and included fourpoint Likert-scale questions. The students were asked to evaluate their attitude towards technology by giving a quantitative value on MALL tools (see Table 1).

To reveal students' points of view on MALL platform after having experience in using technology in EFL classroom the post-experimental questionnaire was designed (see Table 4).

In our experiment, we used pre-test and post-test in control and experimental groups to compare participant's level of vocabulary acquisition and measure the degree of change occurring as a result of Quizlet-based learning in one of the groups. In the pre and post-test experiment design, both tests were identical for two groups to obtain meaningful results. The pre-test was administered at the beginning of the EFL course and post-test was given to students after completion of a 72-hour course. The learners' outcomes were recorded to correlate the scores of pre and post-test. The tests were created based on the state English exam format. They lasted for an hour and consisted of two parts: reading (tasks 1-4, 22 questions) and use of English (task 5-6, 20 questions). The test contained the following types of tasks: finding a match (Task 1: № 1-5, Task 3: № 11-16), multiple choice (Task 2: № 6-10), gap-fill (Task 4: № 17-22, Task 5: № 23-32, Task 6: № 33-42). Each correct answer was graded with 1 point, which adds up to a maximum score of 42 points. The common score required by most universities for Master course is 12 (0-11 is not passed). The results of the pre-test and the post-test were then analysed to verify the hypothesis research.

\section{Results}

The results of the pre-experimental questionnaire (Table 1) showed that the majority of participants $70 \%$ spend most of their time surfing the Internet, $20 \%$ of respondents spend a lot of time (often) engaged with media. In contrast, only $10 \%$ of participants surf the Web rarely. $80 \%$ of respondents were taught with traditional tools (books/paper). It should be mentioned that the students who participated in the survey came from rural schools and colleges. And only $10 \%$ of participants have the experience of using laptops /tablets and smartphones during the lessons respectively. This is not surprising that technology was used rarely (70\%) and never (30\%) in the EFL classroom. 10\% of students use "other" platforms for studying English. The rest of the students have never used any educational platforms. The results of the diagnostic test showed that the participants are of lower-intermediate English level knowledge. 
Table 1. Student opinions about technology

\begin{tabular}{|l|c|c|c|c|}
\hline \multirow{2}{*}{ 1. How often do you surf the Web } & Very often & Often & Rarely & Never \\
\cline { 2 - 5 } & 49 & 14 & 7 & \\
\hline \multirow{2}{*}{$\begin{array}{l}\text { 2. What tools do you mostly use to } \\
\text { study within the class? }\end{array}$} & Books/paper & $\begin{array}{c}\text { Laptop/ } \\
\text { tablet }\end{array}$ & Smartphone & None \\
\cline { 2 - 5 } & 56 & 7 & 7 & \\
\hline \multirow{2}{*}{$\begin{array}{l}\text { 3. How often is the technology used } \\
\text { in the EFL classroom? }\end{array}$} & Every lesson & Often & Rarely & Never \\
\cline { 2 - 5 } & & & 49 & 21 \\
\hline $\begin{array}{l}\text { 4. What online platform do you use } \\
\text { to master your vocabulary? }\end{array}$ & Quizlet & FluentU & Another platform & None \\
\cline { 2 - 5 } & & & 7 & 63 \\
\hline
\end{tabular}

It is well known that to increase the quality of foreign language learning each up-to-date ICT tool shouldn't be used randomly and unmethodically. The effective functioning of Quizlet as Mobile Assisted Language Learning tool should be based on principles. The most important, to our mind, is targeting. Therefore, taking into account the format of the state English exam, the primary goal of our extracurricular intensive course is acquiring as many words as possible. The root word may be modified with prefixes and suffixes, antonyms and synonyms to memorise new vocabulary faster.

The integrated approach is essential in language learning because deep word knowledge is based on multiple experiences with a word. Integrated vocabulary instruction leads to better vocabulary acquisition. Quizlet doesn't provide the integration of four skills in the full sense of this word. It integrates elementary skills like pronunciation rather than speaking and listening. All the flashcards are provided with audio samples, so the students could imitate the voice. Quizlet helps to master spelling not writing skills. This is precisely why we, first of all, focused on the context the words and phrases are used in.

Students' vocabulary can only be activated effectively if the teacher gives the learners opportunities to practice them through vocabulary exercises or activities. Regular reviewing results in good vocabulary achievement. Our previous EFL teaching experience showed that the students find it difficult to recall a new word or phrase within a few days. Consequently, our task was to develop a scheme of word revision to store vocabulary information over a long period.

The technique we applied in our research is called spaced repetition or spaced learning, based on the Ebbinghaus forgetting curve. German psychologist is considered to be a pioneer in the experimental study of memory and the author of the learning curve. According to Hermann Ebbinghaus (cited by Shrestha, 2017), memory retention is $100 \%$ at the time of learning. However, it decreases rapidly to $40 \%$ within the first days. So far as we had two day-by-day classes on Wednesdays and Thursdays spaced repetition was easy to implement. As a rule, we used the following schedule during our intensive courses: 5 minutes of reviewing the set we have created at the end of the period, remembering session based on Quizlet at home, reviewing session (tests, quizzes also based on Quizlet) at the beginning of Thursday period. Moreover, we always revised the previous sets of words. In general, we designed 20 Quizlet modules. At the end of our intensive course study, the students of both groups wrote the final testing. The time and the tasks were of the same content and difficulty they had been at the beginning of their learning. Table 2 reports the comparative results of the pre and post-experimental testing.

Table 2. Control and experimental groups' pretest-posttest achievement scores on general testing

\begin{tabular}{|l|c|c|c|c|c|c|c|}
\hline \multicolumn{4}{|c|}{ Pre-experimental general testing } & \multicolumn{3}{c|}{ Post experimental general testing } \\
\hline $\begin{array}{c}\text { Experimental group } \\
(\mathbf{n = 2 5})\end{array}$ & \multicolumn{2}{c|}{$\begin{array}{c}\text { Control group } \\
(\mathbf{n = 2 5})\end{array}$} & \multicolumn{2}{|c|}{$\begin{array}{c}\text { Experimental group } \\
(\mathbf{n = 2 5})\end{array}$} & $\begin{array}{l}\text { Control group } \\
(\mathbf{n = 2 5})\end{array}$ \\
\hline $\begin{array}{l}\text { N/ } \\
\text { students }\end{array}$ & Score & $\begin{array}{l}\text { N/ } \\
\text { students }\end{array}$ & Score & $\begin{array}{l}\text { N/ } \\
\text { students }\end{array}$ & Score & $\begin{array}{l}\text { N/ } \\
\text { students }\end{array}$ & Score \\
\hline 1 & $\mathbf{1 9}$ & 1 & $\mathbf{2 0}$ & 2 & $\mathbf{2 0}$ & 1 & $\mathbf{1 9}$ \\
\hline 2 & $\mathbf{1 6}$ & 2 & $\mathbf{1 7}$ & 2 & $\mathbf{1 9}$ & 1 & $\mathbf{1 8}$ \\
\hline 3 & $\mathbf{1 4}$ & 5 & $\mathbf{1 6}$ & 2 & $\mathbf{1 7}$ & 2 & $\mathbf{1 7}$ \\
\hline 4 & $\mathbf{1 3}$ & 4 & $\mathbf{1 4}$ & 3 & $\mathbf{1 6}$ & 2 & $\mathbf{1 6}$ \\
\hline
\end{tabular}




\begin{tabular}{|c|c|c|c|c|c|c|c|}
\hline 3 & $\mathbf{1 2}$ & 5 & $\mathbf{1 1}$ & 4 & $\mathbf{1 5}$ & 2 & $\mathbf{1 5}$ \\
\hline 5 & $\mathbf{1 1}$ & 3 & $\mathbf{9}$ & 5 & $\mathbf{1 4}$ & 4 & $\mathbf{1 4}$ \\
\hline 3 & $\mathbf{1 0}$ & 2 & $\mathbf{8}$ & 1 & $\mathbf{1 3}$ & 2 & $\mathbf{1 3}$ \\
\hline 4 & $\mathbf{7}$ & 2 & $\mathbf{7}$ & 4 & $\mathbf{1 2}$ & 4 & $\mathbf{1 2}$ \\
\hline- & - & 1 & $\mathbf{6}$ & 2 & $\mathbf{1 1}$ & 5 & $\mathbf{1 1}$ \\
\hline- & - & - & - & - & - & 2 & $\mathbf{9}$ \\
\hline Average & $\mathbf{1 1 . 7 6}$ & Average & $\mathbf{1 2 . 3 2}$ & Average & $\mathbf{1 4 . 9 2}$ & Average & $\mathbf{1 3 . 0 8}$ \\
\hline
\end{tabular}

Table 2 reveals that achievement test scores of control group students before treatment (12.32) was higher than the experimental group students' score (11.76), but this difference is not significant (0.56). Hence, it may be concluded that at the beginning of the project, the experimental and the control groups were almost comparable in prior foreign language achievement; both groups made progress during the foreign language course. Interestingly, but the experimental group revealed better results in post-experimental testing compared to the control group, despite the lower foreign language achievement in the pre-test. We showed the difference between scores in pretest-posttest in control and experimental groups in Table 3.

Table 3.The difference in individual scores in the pre- and post-experimental general testing

\begin{tabular}{|l|l|l|l|l|l|}
\hline Experimental group & Pre-test & Post-test & Control groups & Pre-test & Post-test \\
\hline$(\mathrm{n}=25)$ & 11.76 & 14.92 & $(\mathrm{n}=25)$ & 12.32 & 13.08 \\
\hline Difference & +3.16 & Difference & +0.76 & \\
\hline
\end{tabular}

Table 3 suggests a higher achievement in vocabulary acquisition in favour of the experimental group. The difference between means of the control and experimental groups was about 3.16 points. Obtained data make it possible to confirm that the experimental group benefits from the proposed Quizlet based strategy (7\% of vocabulary increase) when compared to the control group (3\% of the increase). But we also can state that our Quizlet based instruction also helped students to experience the positive impact of ICT tools in learning. In our post-survey questionnaire, the students of the experimental group were able to show their attitude towards MALL technology based on their in and out-class activities. The questionnaire sample is given in Table 4.

Table 4. Advantages and disadvantages of MALL technology

\begin{tabular}{|l|c|c|c|c|}
\hline $\begin{array}{c}\text { MALL technology can challenge you } \\
\text { to do your work better }\end{array}$ & $\begin{array}{c}\text { Strongly } \\
\text { agree }\end{array}$ & Agree & Disagree & $\begin{array}{c}\text { Strongly } \\
\text { disagree }\end{array}$ \\
\hline $\begin{array}{l}\text { 1.Easy: easy to use; makes learning and } \\
\text { finding information easier }\end{array}$ & 7 & 18 & & \\
\hline 2.Fast / saves time & 5 & 20 & & \\
\hline $\begin{array}{l}\text { 3.Learn new: information; things; } \\
\text { technology; ways of learning }\end{array}$ & 8 & 17 & & \\
\hline 4.Interesting / fun / not boring & 23 & 2 & & \\
\hline 5. Visuals help to learn & 21 & 4 & & \\
\hline 6.Enables creativity & 4 & 10 & 11 & \\
\hline
\end{tabular}

The final questionnaire was designed to determine students' attitude towards ICT technology based on their Quizlet learning experience in the EFL classroom. We reduced data from the Likert scale to the nominal level by combining all agree and disagree into two categories of accepting and reject. The findings of a Likert scale survey showed that all the students in the experimental group agreed that MALL technology can challenge them to do their work better because it makes learning and finding information easier, saves time, is interesting and effective (visuals help to learn). It's not surprising that $44 \%$ of respondents didn't agree that MALL technology enables creativity. We realised that during the experiment Quizlet-based activities were focused rather on developing the potential of long-term memory in terms of vocabulary acquisition than enhancing creativity.

\section{Discussion}

The aim of this study was to examine the effectiveness of Quizlet platform in EFL classroom with the A2 level students at extracurricular intensive language courses. Such characteristic of laptops and 
smartphones as portability encouraged developing new teaching styles that are believed to enhance English language learning. When we talk about Quizlet-based activities we can't but mention the graphic presentation of the words located in the program sets. The principle of cognitive visualisation is applied to the MALL tool. The potential of the right hemisphere was used to increase the level of vocabulary memorisation. We are sure that linking unknown words with images benefits vocabulary acquisition. The students were encouraged to use bright graphics and exaggerated pictures when creating Quizlet modules.

We compared the level of vocabulary acquisition with the students of experimental and control groups. After examining the outcomes of 50 students who didn't have much experience of using MALL platforms in their studying, our statistical analysis concluded that the implementation of Quizlet in EFL learning and scheduling platform activities according to spaced repetition can improve vocabulary acquisition at $7 \%$.

Our findings suggest that the students who were taught foreign language vocabulary at intensive language courses through traditional paper notebooks had no better outcomes than the students who worked based on Quizlet platform. The positive impact of Quizlet for vocabulary has been proved experimentally. The results of the study agree with the previous research and consider Quizlet to be an effective digital learning tool (Ashcroft \& Imrie, 2014; Andarab, 2017; Sanosi, 2018; Dizon, 2016; Fageeh, 2013; Jackson, 2015; Lu, 2008; Taj et al., 2016; Montaner-Villalba, 2019). However, our research paper demonstrated that Quizlet is a useful ICT tool in vocabulary learning due to its ability to incorporate integrated skills and cognitive visualisation. Scientists developed practical guidance for teachers on how to use Quizlet flashcards in EFL learning (Ashcroft \& Imrie, 2014). Our study also describes the procedure of Quizlet-based learning with the low proficiency English users in Ukraine. Barr (2016) admits that "failed to motivate continuous vocabulary development" and to perform "spaced repetition" (p. 46).

Although previous findings indicated that on-line vocabulary platform can boost vocabulary learning at 6\% (Lander, 2015), our study followed the psychological approach to Quizlet instructions that made it possible to get higher results. It is possible that outcomes would vary if measured over a two or three year period of time. But then the survey should be conveyed in stable groups during the obligatory foreign language course. Our experiment provided a new insight into Quizlet vocabulary learning taking into account the principles of Ebhherhouse forgetting curve. That is why during our experiment we paid particular attention to the procedure of spaced repetition. We never missed vocabulary spaced repetition in class and send reminders via mas media groups. We expected to improve students' vocabulary acquisition at $5 \%$ because we were sure that using Quizlet instead of traditional vocabulary notebooks can enhance students learning. However, the results turned out to be 2\% higher due to developing Quizlet instructions in compliance with Ebhherhouse forgetting curve.

Besides, most previous surveys on Quizlet-based vocabulary learning were conducted in Japanese universities. Our study considers university experience in vocabulary learning via an online platform in Ukrainian High School.

The investigation revealed that Quizlet based EFL learning can benefit vocabulary acquisition. On this basis, online vocabulary platforms should be used in EFL classroom not only at extracurricular intensive foreign language courses but also at university foreign language classes integrating different methods of repetition. It is therefore recommended to use Quizlet with carefully planned vocabulary drilling according to the principles of Ebhherhouse forgetting curve.

\section{Conclusion}

The latest trends of teaching, as well as the huge advance of technology, allow teachers to utilise online and mobile applications through diverse apps. The appropriate implementation of ICT in the EFL classroom helps the learners to improve their vocabulary acquisition and maximise target outcomes. The use of such online platform as Quizlet to prepare A2 level students for state English exam utilising spaced repetition technique will benefit vocabulary learning.

Future researches should consider investigating the impact of two different vocabulary platforms over a longer period (two years or longer). Regardless, our results point to the need for teachers to use Quizletbased learning in extracurricular intensive foreign language courses or as a part of in-class activities.

\section{References:}

Andarab, M. S. (2017). The effect of using Quizlet flashcards on learning English Vocabulary. In M. Vihar (Ed.), Proceedings of 113th IIER International Conference (pp.37-41). Frankfurt, Germany.

Ashcroft, R. J., Cvitkovic, R., Praver, M. (2018). Digital flashcard L2 Vocabulary learning out-performs traditional flashcards at lower proficiency levels: A mixed-methods study of 139 Japanese university students. The Eurocall Review, 26 (1), 14-28. https://doi.org/10.4995/eurocall.2018.7881 
Ashcroft, R. J., \& Imrie, A. C. (2014). Learning vocabulary with digital flashcards. In N. Sonda \& A. Krause. (Eds.), JALT2013 Conference Proceedings. Tokyo: JALT.

Barr, B. (2016). Checking the effectiveness of Quizlet as a tool for vocabulary learning. The Centre for ELF Journal, 1 (2), 36-48. Retrieved 11 November 2018 from https://pdfs.semanticscholar.org/9ce3/35781dee4292083a046040f97898bcd526ff.pdf

British Council (2019). Online English level test. Retrieved 9 September 2019 from https://learnenglish.britishcouncil.org/

Chaikovska, O. V., Zbaravska, L. Yu., Bilyk, T. L. (2019). Podcasts in teaching EFL for students majoring in engineering. In A. Aboltis (Ed.), Proceedings of 18th International Scientific Conference "Engineering for Rural Development” (pp. 19151920). Latvia, Jelgava. https://doi.org/10.22616/ERDev2019.18.N344

Dizon, G. (2017). Quizlet in the EFL classroom: Enhancing academic vocabulary acquisition of Japanese university students. Teaching English with technology, 16 (2), 40-56. Retrieved 11 November 2019 from from https://www.tewtjournal.org/

Fageeh, I. (2013). Effects of MALL applications on vocabulary acquisition and motivation. Arab World English Journal, 4 (4), $420-$ 447. Retrieved 11 July 2018 from https://awej.org/images/AllIssues/Volume4/Volume4Number4Dec2013/25.pdf

Jackson, D. B. (2015). A targeted role for L1 in L2 vocabulary acquisition with mobile learning technology. Perspectives, 23, (1), 611. Retrieved 20 August 2019 from http://issuu.com/tesolarabia-perspectives/docs/feb2015-perspectives.

Kilickaya, F., Krajka, J. (2010). Comparative usefulness of online and traditional vocabulary learning. TOJET: The Turkish Online Journal of Educational Technology, 9, (2), 55-63. Retrieved 1 October 2019 from https://eric.ed.gov

Lu, M. (2008). Effectiveness of vocabulary learning via mobile phone. Journal of Computer Assisted Language Learning, 24, 515525. https://doi.org/10.1111/j.1365-2729.2008.00289.x

Lander, B. (2015). Lesson study at the foreign language university level in Japan: blended learning, raising awareness of technology in the classroom. International Journal for Lesson and Learning Studies, 4 (4), 362-382. https://doi.org/10.1108/IJLLS-02-2015-0007

Miangah, T. M., Nezarat, A. (2012). Mobile-Assisted Language Learning. International Journal of Distributed and Parallel Systems, 3 (1), 309-319. https://doi.org/ 10.5121/ijdps.2012.3126

Ministry of Education and Science of Ukraine (2019). Conceptual fundamentals of the State policy on development of the English language in higher education. Retrieved 1 August 2019 from https://mon.gov.ua/

Montaner-Villalba, S. (2019). The use of Quizlet to enhance vocabulary in the English language classroom. In F. Meunier, J. Van de Vyver, L. Bradley \& S. Thouësny (Eds), CALL and complexity - short papers from EUROCALL 2019 (pp. 304-309). Research-publishing.net. https://doi.org/10.14705/rpnet.2019.38.1027

Sanosi, A.B. (2018). The Effect of Quizlet on Vocabulary Acquisition. Saudi Arabia Asian Journal of Education and e-Learning, 6 (4), 71-76. https://doi. 10.24203/ajeel.v6i4.5446

Shrestha, P. (November 17, 2017) "Ebbinghaus Forgetting Curve". Psychestudy. Retrieved 26 December 2019 from https://www.psychestudy.com/cognitive/memory/ebbinghaus-forgetting-curve

Stockwell, G. (2010). Using mobile phones for vocabulary activities: Examining the effect of the platform. Language Learning \& Technology, 14 (2), 95-110. Retrieved 6 September 2018 from http://llt.msu.edu/ vol14num2/stockwell.pdf.

Taj, H., Sulan, N. B., Sipra, M. A., \& Ahmad, W. (2016). Impact of Mobile Assisted Language Learning (MALL) on EFL: A MetaAnalysis. Advances in language and literary studies, 7(2), 76-83. http://dx.doi.org/10.7575/aiac.alls.v.7n.2p.76 